\title{
Attitudes of Polish physicians towards new antihypertensive agents $-a$ final report from the ALMONDS survey
}

\author{
Postawy polskich lekarzy wobec nowych leków hipotensyjnych \\ - raport końcowy z ankietowego badania ALMONDS
}

\author{
Krzysztof J. Filipiak ${ }^{1}$, Aleksandra Gąsecka ${ }^{1}$, Marcin Lewandowski ${ }^{2}$, Bartosz Krzowski ${ }^{1}$, \\ Anna E. Płatek ${ }^{1}$, Filip M. Szymański ${ }^{1}$, Beata Wożakowska-Kapłon ${ }^{3}$, Andrzej Tykarski ${ }^{4}$ \\ ${ }^{1} 1^{\text {st }}$ Chair and Department of Cardiology, Medical University of Warsaw, Warsaw, Poland \\ ${ }^{2}$ School of Business, Technical University of Warsaw, Warsaw, Poland \\ ${ }^{3} 1^{\text {st }}$ Clinical Department of Cardiology, Swietokrzyskie Centre of Cardiology, The Jan Kochanowski University, Kielce, Poland \\ ${ }^{4}$ Department of Hypertension, Angiology, and Internal Medicine, Poznan University of Medical Sciences, Poznań, Poland
}

\section{Abstract}

Introduction. Arterial hypertension is the most frequent modifiable risk factor for cardiovascular disease and premature mortality globally. Availability of novel antihypertensive agents with unique pharmacological characteristics improves the efficacy and safety of antihypertensive therapy. The aim of the ALMONDS survey was to identify the attitude of Polish medical professionals towards novel pharmacological agents used in the therapy of hypertension. In particular, we sought to investigate the views regarding the "class effect" for antihypertensive agents.

Material and methods. The study was conducted using a standardized survey, which was filled in by 784 specialists or trainees in cardiology, internal medicine, family medicine, and diabetology. The letter form and anonymity of the survey allowed to maximize the reliability of the collected data.

Results. The majority of the study group were females 46-60 years of age. A substantial proportion of the physicians specialized in internal medicine and had more than 20 years of professional experience. The management was mostly guided by the Polish Society of Hypertension (PTNT) guidelines or the European Society of Hypertension (ESH)/European Society of Cardiology (ESC) guidelines. In patients with hypertension and coronary artery disease, the most commonly chosen drug treatment included a beta-blocker and an angiotensin-converting enzyme (ACE) inhibitor or an ACE inhibitor and a vasodilating beta-blocker. The latter combination was also selected most frequently in patients with hypertension and heart failure. In women in reproductive age, a vasodilating beta-blocker and a calcium antagonist were selected most frequently, while a combination of nebivolol and zofenopril was indicated as the best in young men with hyperkinetic circulation. In patients with resistant hypertension, the most frequently chosen regimen included furosemide, amlodipine, zofenopril, and nebivolol. Another popular combination included torasemide, lercanidipine, telmisartan, and carvedilol.

Conclusions. The results of our study indicate that Polish medical professionals have clear preferences regarding specific pharmacological agents within drug classes. Vasodilating agents are preferred among beta blockers, newer agents among ACE inhibitors, dihydropyridines among calcium antagonists, and loop diuretics among diuretics. This attitude is generally consistent with the 2015 PTNT guidelines.

Key words: arterial hypertension, antihypertensive agents, guidelines, health care surveys

Folia Cardiologica 2016; 11, 2: 85-95

Address for correspondence: lek. Aleksandra Gąsecka, I Katedra i Klinika Kardiologii, Warszawski Uniwersytet Medyczny, ul. Banacha 1a, 02-097 Warszawa, e-mail: aleksandra.gasecka@wum.edu.pl 


\section{Introduction}

Hypertension is the most common modifiable risk factor for cardiovascular disease globally, responsible for 7.6 million premature deaths (in subjects < 69 years of age), or $13.5 \%$ of all deaths [1]. Global prevalence of hypertension has been estimated at 970 million, including 330 million in the developed countries [2]. The NATPOL 2011 epidemiological study, evaluating hypertension and other cardiovascular risk factors in Poland, indicated that also in our country, hypertension is the second most common cardiovascular risk factor after hyperlipidaemia, present in 32\% (10.5 million) adult Poles [3]. Despite a two-fold increase in the proportion of patients with controlled hypertension found in 2011 compared to 2002 , still about $30 \%$ of hypertensive subjects (3.1 million) are not aware of this diagnosis. At the same time, the Monitoring of Trends and Determinants in Cardiovascular Disease (MONICA) project by the World Health Organization showed that the reduction in cardiovascular mortality observed since mid-1980s may be attributed in two thirds to better risk factor control and reduced disease incidence, and in only one third to more effective treatment [4].

Adequate blood pressure control is often a challenge in clinical practice. This is related to patient non-compliance, the most common cause of pseudoresistance to multi-drug treatment [5], and physician non-adherence to the recommendations regarding antihypertensive drug therapy [6]. Results of large randomized clinical trials published in the recent years created new opportunities for individualizing the management of hypertension using specific antihypertensive drugs within drug classes or their fixed-dose combinations. Currently available scientific data were reflected in the new guidelines on the management of hypertension, developed by the experts of the Polish Society of Hypertension (PTNT, Polskie Towarzystwo Nadciśnienia Tętniczego) and released in May 2015 at a conference of the "Nadciśnienie Tętnicze" journal [7].

The aim of the ALMONDS (Are ALI pills equal within the MajOr hypotensive Drug classeS?) survey was to identify the attitude of Polish physicians toward new drugs used in the treatment of hypertension. Importantly, we wanted to learn the opinion of Polish medical professionals regarding the current principles of antihypertensive therapy, in particular the class effect for antihypertensive agents, or a claim that all drugs are equal within a given antihypertensive drug class.

\section{Material and methods}

The study was performed using a standardized survey approach. For this purpose, we used a questionnaire that was sent to the participating physicians along with an introductory letter prepared by the study authors. The individual survey approach allowed the participants to choose answers to particular items among the proposed categories (multiple choice questionnaire), which allowed comparing results between the participants. The answers provided were entered to an electronic database and analysed quantitatively using statistical methods. The advantage of the approach used was an avoidance of the interviewer effect, i.e. a purposeful or unintended influence of the interviewer/researcher on the answers given, increasing reliability of the results. According to the Personal Data Protection Act, information obtained from the respondents was kept confidential and used only to compile summary statistics that included no data that might allow identification of the respondent.

The study protocol was submitted to the Bioethics Committee at the Medical University of Warsaw which had no objections to both the content of the questionnaire and the study concept.

The study was conducted in the period from July to September 2015 and covered the whole country. Overall 784 specialists or trainees in cardiology, internal medicine, diabetology, and family medicine participated in the study. The study results regarding the physicians' attitude towards new antihypertensive agents were reported in relation to gender, age, place of work, specialization, professional experience, and practice settings. To report medical professionals' answers in relation to their place of work, the whole country Poland was divided into four areas as shown on Figure 1.

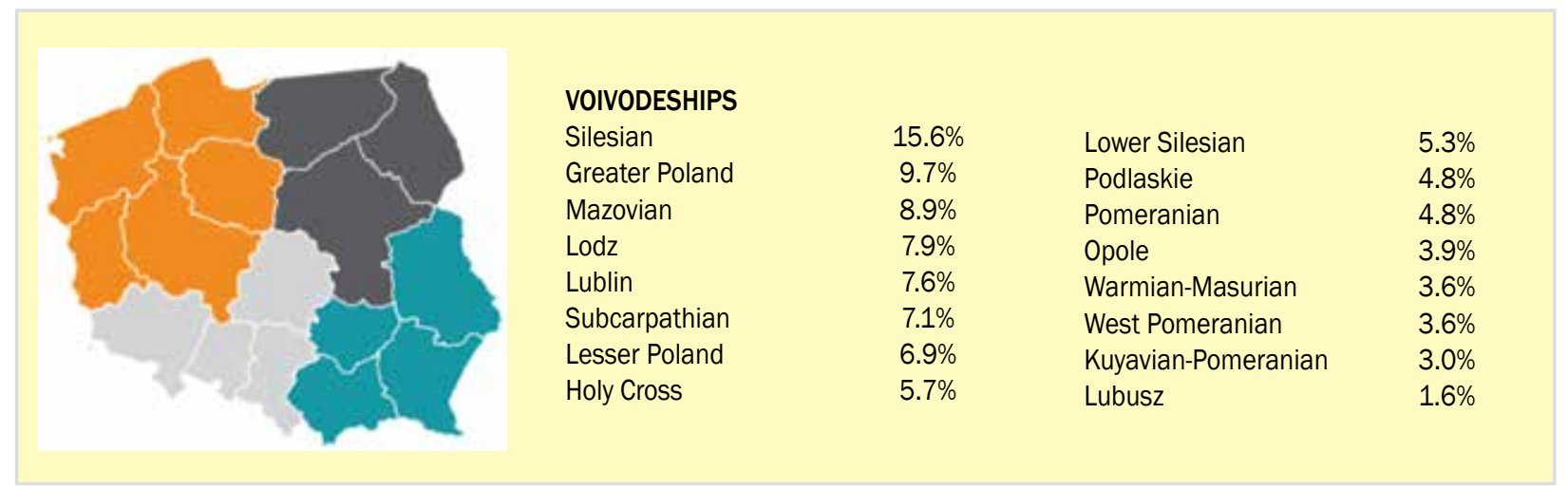

Figure 1. Place of work of the participating physicians 
Table 1. Characteristics of the surveyed physician population

\begin{tabular}{|c|c|}
\hline Parameter & Percentage [\%] \\
\hline \multicolumn{2}{|l|}{ Gender } \\
\hline Men & 46 \\
\hline Women & 54 \\
\hline \multicolumn{2}{|l|}{ Age [years] } \\
\hline$<29$ & 3.7 \\
\hline $30-45$ & 37.4 \\
\hline $46-60$ & 50.7 \\
\hline$>61$ & 8.2 \\
\hline \multicolumn{2}{|l|}{ Specialization } \\
\hline Internal medicine & 46.2 \\
\hline Family medicine & 26.2 \\
\hline Cardiology & 25.8 \\
\hline Diabetology & 1.1 \\
\hline \multicolumn{2}{|c|}{ Professional experience [years] } \\
\hline$<10$ & 16.1 \\
\hline $10-20$ & 36.6 \\
\hline$>20$ years & 47.3 \\
\hline \multicolumn{2}{|l|}{ Practice settings } \\
\hline Outpatient & 74.6 \\
\hline Inpatient & 25.4 \\
\hline
\end{tabular}

\section{Results}

\section{Study group characteristics}

More than half (50.7\%) of the participating physicians were aged $46-60$ years, and $46 \%$ of the study participants were men. Three voivodeships with the highest number of participants were Silesian, Greater Poland, and Mazovian (15.6\%, $9.7 \%$, and $8.9 \%$ of participating physicians, respectively). Internal medicine specialists comprised $46.2 \%$ of the study group, family medicine specialists comprised $26.9 \%$, cardiologists comprised $25.8 \%$, and diabetes specialists comprised $1.1 \%$. Nearly half of the participants (47.3\%) had more than 20 years of professional experience, followed by physicians with 11-20 years of professional experience (36.6\%), and the smallest group were physicians with less than 10 years of professional experience (16.1\%). Three fourths $(74.6 \%)$, of the participants practiced in outpatient settings and one fourth (25.4\%) practiced in hospital settings. The demographic, geographic, and professional characteristics of the study population are shown in Table 1 and Figure 1.

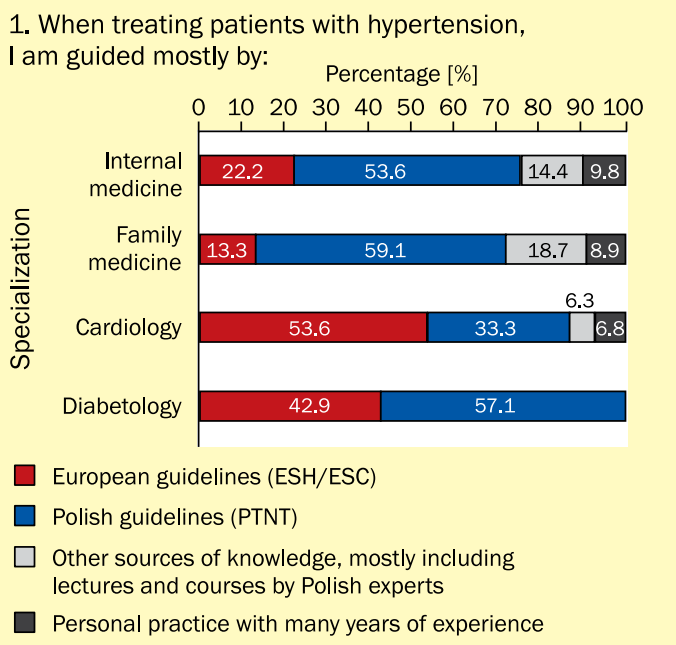

Figure 2. Sources of knowledge affecting management decisions of Polish physicians depending on their specialization; ESH - European Society of Hypertension; ESC - European Society of Cardiology; PTNT (Polskie Towarzystwo Nadciśnienia Tętniczego) - Polish Society of Hypertension

\section{Sources of knowledge underlying management decisions of Polish medical professionals}

Participating physicians declared that their decisions regarding the management of hypertensive patients were mostly based on the PTNT guidelines (57.3\% of women and $42.2 \%$ of men) and the European Society of Hypertension (ESH)/ European Society of Cardiology (ESC) (24.3\% of women and $32.0 \%$ of men). Other indicated sources included lectures and courses by Polish experts (12.2\% of women and $15 \%$ of men), and personal practice with many years of experience (6.2\% of women and $10.8 \%$ of men). Physicians $\geq 30$ years of age mostly indicated the PTNT guidelines (46.9-56.7\% of the respondents in various age groups), while physicians $<29$ years of age mostly indicated the European guidelines (39.3\%). Cardiologists were the only group that mostly made decisions guided by the European guidelines (53.6\%), while the PTNT guidelines were most popular source of knowledge for internal medicine, family medicine, and diabetes specialists (53.6-59.1\%), as shown in Figure 2.

When planning antihypertensive therapy, hospital specialists were more frequently guided by the European guidelines (49.2\%), while specialists practicing in outpatient settings were mostly guided by the PTNT guidelines (54.4\%). None of the participants reported being guided by the Joint National Committee (JNC) guidelines when making management decisions. 
2. For me, the most important management goal in patients with hypertension is: Percentage [\%]

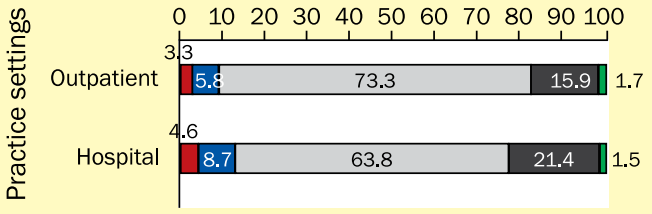

Maximum blood pressure reduction

Blood pressure reduction to values defined in the guidelines as maximum normal values

$\square$ Blood pressure reduction to normal values or as close to normal values as possible and reduction of global cardiovascular risk

$\square$ Patient protection from such events as myocardial infarction, stroke, and death

Achieving normal 24-hour BP monitoring values

Figure 3. Declared goals of the management of hypertension depending on practice settings; $\mathrm{BP}$ - blood pressure

\section{Goals of antihypertensive therapy}

The most important management goal in patients with hypertension, declared by both women (72.3\%) and men $(69.4 \%)$, was blood pressure reduction to normal values or as close to normal values as possible and reduction of global cardiovascular risk. Other declared goals included protection from such events as myocardial infarction, stroke, and death ( $16.6 \%$ of women and $18.7 \%$ of men), blood pressure reduction to values defined as maximum normal $(7.1 \%$ of women and $18.7 \%$ of men), maximum blood pressure reduction (3\% of women and $4.4 \%$ of men), and achieving normal 24-hour BP monitoring values (1\% of women and $2 \%$ of men). This response distribution was similar in all age groups regardless of the place of work, specialization, professional experience, and work settings. Diabetologists considered achieving normal 24-hour BP monitoring values the most important management goal more frequently than other specialists $(12.5 \%$ vs. $1-1.7 \%$ among other specialists). Hospital specialists considered protection from myocardial infarction, stroke, and death the most important management goal more frequently than specialists practicing in outpatient settings $(21.4 \%$ vs. 15.9\%). Declared goals of the management of hypertension depending on practice settings are shown in Figure 3.

\section{Management of hypertension \\ in special patient populations}

When the respondents were asked to select the best regimen for patient groups listed below, they were allowed to indicate more than one treatment option.

In patients with hypertension and diabetes, the most commonly chosen regimen was a combination of an angiotensin-converting enzyme (ACE) inhibitor and a calcium
3. In patients with hypertension and diabetes my preferred choice would be*:

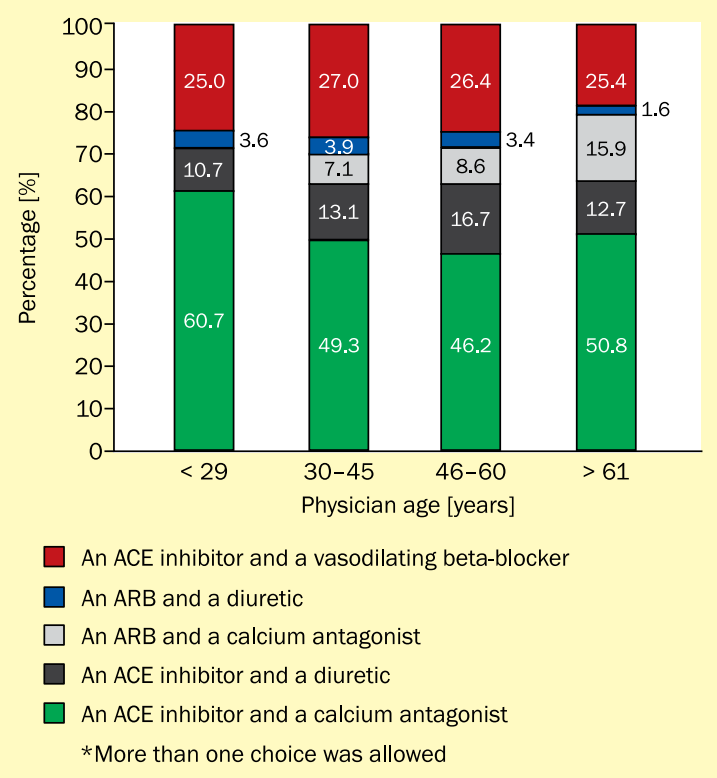

Figure 4. Management of hypertension in patients with concomitant diabetes depending on physician's age; ACE - angiotensin-converting enzyme

antagonist (46.7\% of women and $50.9 \%$ of men), followed by an ACE inhibitor and a vasodilating beta-blocker (26.3\% of women and $25.7 \%$ of men). Less frequently chosen combinations included an ACE inhibitor and a diuretic $(17.4 \%$ of women and $12.1 \%$ of men), an angiotensin receptor blocker (ARB) and a calcium antagonist (8.7\% of women and $8.4 \%$ of men), and least frequently an ARB and a diuretic (3\% of women and $3.5 \%$ of men). The combination of an ACE inhibitor and a calcium antagonist was most commonly chosen by the youngest physicians ( $<29$ years of age), as illustrated in Figure 4 . This regimen was also more popular among diabetologists $(62.5 \%)$ and cardiologists (55.4\%) than among internal medicine specialists (47.1\%) and family medicine specialists (45.5\%). It was also more popular among hospital specialists (56.4\%) compared to those practicing in outpatient settings (46.2\%).

In patients with hypertension and established coronary artery disease, the most popular treatment regimen was a combination of an ACE inhibitor and a beta-blocker ( $44.7 \%$ of women, $41.2 \%$ of men) or a vasodilating beta-blocker ( $41.8 \%$ of women, $42.9 \%$ of men). Much less frequently recommended regimens included an ACE inhibitor and a calcium antagonist (7.9\% of women and $9 \%$ of men), an ACE inhibitor and a diuretic (3.9\% of women and $4.1 \%$ of men), and a beta-blocker and a calcium antagonist (3.4\% of women and $3.8 \%$ of men). A combination of an ACE inhibitor and a beta-blocker was most commonly chosen be physicians < 29 years of age. Management decisions 


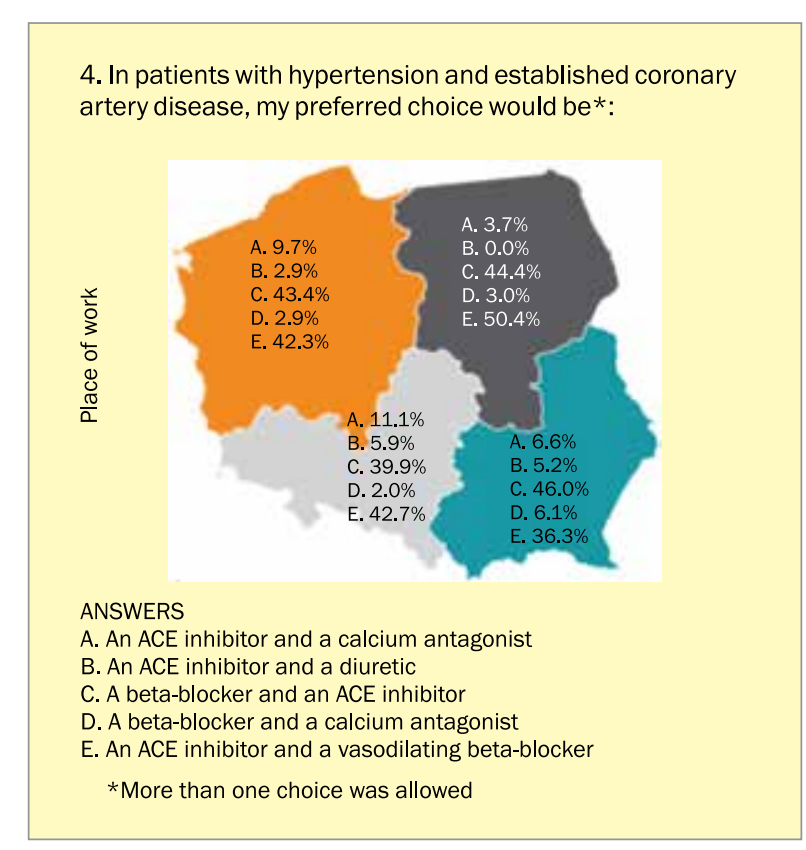

Figure 5. Management of hypertension in patients with concomitant coronary artery disease depending on the place of work; ACE - angiotensin-converting enzyme

in this patient group also showed significant geographical variation, as illustrated in Figure 5. A combination of an ACE inhibitor and a beta-blocker was not chosen by any diabetologist, while it was the most popular combination among cardiologists and internal medicine specialists (49.7\% and $46.3 \%$, respectively). Instead, $50 \%$ of diabetologists would choose therapy with an ACE inhibitor and a vasodilating beta-blocker.

In patients with hypertension and heart failure, a large majority of the surveyed physicians would choose an ACE inhibitor and a vasodilating beta-blocker (56.5\% of women and $63.6 \%$ of men), as illustrated in Figure 6 . The second most commonly chosen treatment option was a combination of an ACE inhibitor and an aldosterone antagonist (28.6\% of women and $22 \%$ of men). Much fewer physicians would choose treatment with an ARB and a diuretic $(9.4 \%$ of women and $7.8 \%$ of men) or an ACE inhibitor and a dihydropyridine calcium antagonist (5.7\% of women and $5.5 \%$ of men). Only a small proportion would recommend treatment with an ARB and a dihydropyridine calcium antagonist (1.7\% of women and $2.3 \%$ of men). Compared to other specialists, diabetologists were much more likely to indicate regimens involving a dihydropyridine calcium antagonist or an ARB.

In patients with hypertension and concomitant chronic obstructive pulmonary disease (COPD), the most frequently chosen combination included an ACE inhibitor and a calcium antagonist (39\% of women and $39.9 \%$ of men) or an ARB and a calcium antagonist (30.3\% of women and $26.5 \%$ of men). Less popular choices included a calcium antagonist and a vasodilating beta-blocker (13.2\% of wo-

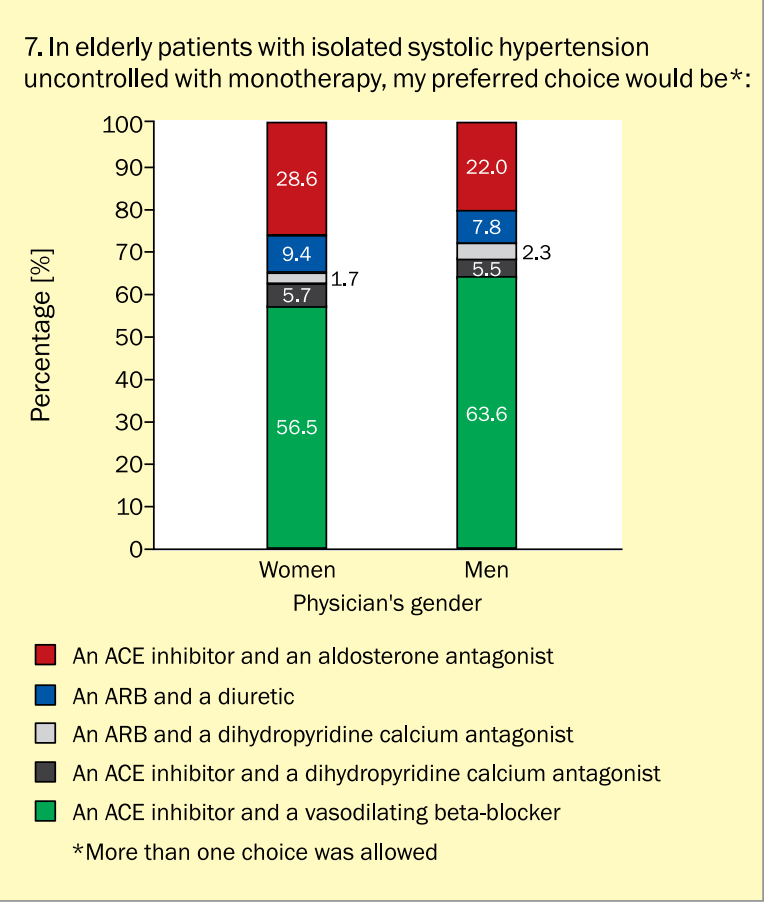

Figure 6. Treatment regimen for hypertension with concomitant heart failure depending on physician' gender; ACE - angiotensin-converting enzyme

men, $14.9 \%$ of men) and an ACE inhibitor and a diuretic (13.4\% of women, $14.6 \%$ of men), while the least commonly indicated choice was a combination of an ARB and a diuretic (5.5\% of women, $6.4 \%$ of men). A regimen of an ACE inhibitor and a calcium antagonist would be recommended by a half of cardiologists (50.3\%), just above one third of family physicians (34.7\%) and internal medicine specialists (34.2\%), and only one fourth of diabetologists (25\%). Instead, diabetologists were more likely to choose a combination of a calcium antagonist and a vasodilating beta-blocker (25\%) or a calcium antagonist and an ARB (25\%). A combination of an ACE inhibitor and a calcium antagonist was also much more popular among hospital specialists (52.3\%) compared to those practicing in outpatient settings (34.2\%), where an equally popular choice was a combination of an ARB and a calcium antagonist (32.3\%).

\section{Antihypertensive treatment}

\section{in patients with resistant hypertension}

In patients with isolated systolic hypertension uncontrolled with monotherapy, the most frequently chosen combination was a diuretic and a calcium antagonist (36.8\% of women and $35.2 \%$ of men). Quite popular regimens also included an ACE inhibitor combined with a diuretic $(21.8 \%$ of women and $27 \%$ of men) or a calcium antagonist $(20.8 \%$ of women and $22.6 \%$ of men). Less popular but still quite common regiments included a vasodilating beta-blocker combined with a calcium antagonist $(9.5 \%$ of women and $9.4 \%$ of 


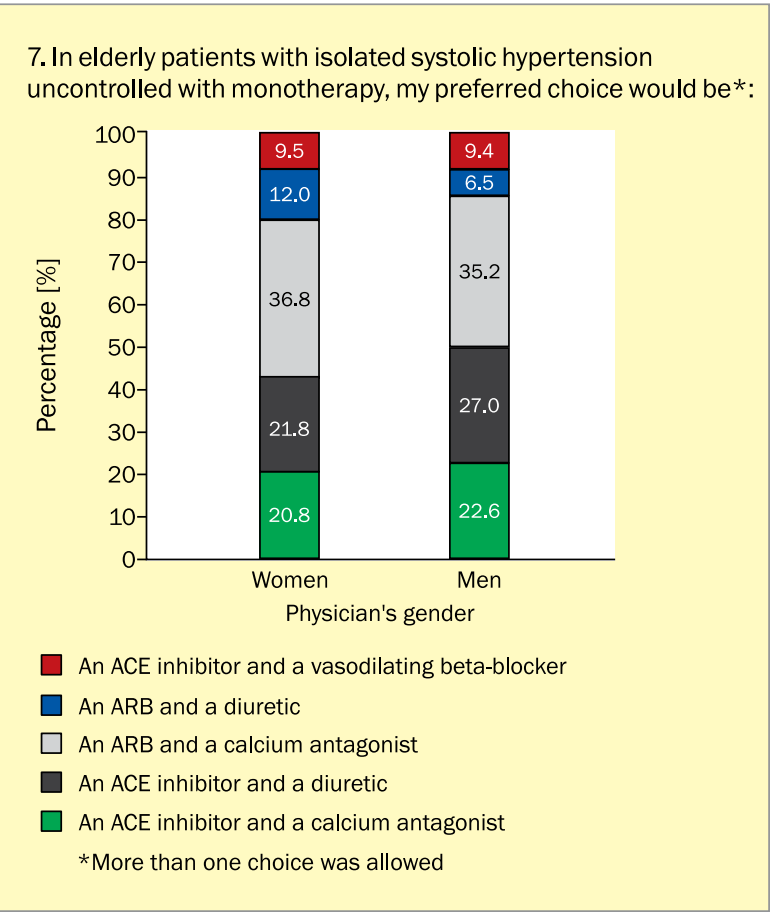

Figure 7. Treatment regimen in elderly patients with isolated systolic hypertension depending on physician's gender; ACE - angiotensin-converting enzyme

men) or an ACE inhibitor (12.0\% of women and $6.5 \%$ of men). Preferred treatment regimens in this patient group depending on physician's age are shown in Figure 7.

In women of reproductive age with hypertension uncontrolled with monotherapy, the most commonly indicated treatment regimen was a combination of a vasodilating beta-blocker and a calcium antagonist (34.9\% of women and $35.7 \%$ of men), followed by a calcium antagonist and a centrally acting drug (26.9\% of women and $29.6 \%$ of men). All other possible responses, including any beta-blocker and a calcium antagonist, a diuretic and a calcium antagonist, and a diuretic and a vasodilating beta-blocker, gained a comparable support among the respondents $(9-14 \%)$. However, opinions of the surveyed physicians showed some variation depending on the place of work and specialization, with the regimen of a calcium antagonist and a centrally acting drug being most popular in the northwestern part of the country and among diabetologists.

In a young man with hypertension and hyperkinetic circulation who is uncontrolled with monotherapy, most respondents would use a regimen of nebivolol and zofenopril ( $77.7 \%$ of women and $71.3 \%$ of men). Much less frequently suggested regimens included bisoprolol and perindopril (14.9\% of women, $21.4 \%$ of men) and carvedilol and ramipril ( $5.4 \%$ of women, $3.8 \%$ of men), and only a marginal proportion of physicians would recommend metoprolol and quinapril or metoprolol XL/CR and trandolapril (0.5-2.3\%).
7. In elderly patients with isolated systolic hypertension uncontrolled with monotherapy, my preferred choice would be*: Percentage [\%]

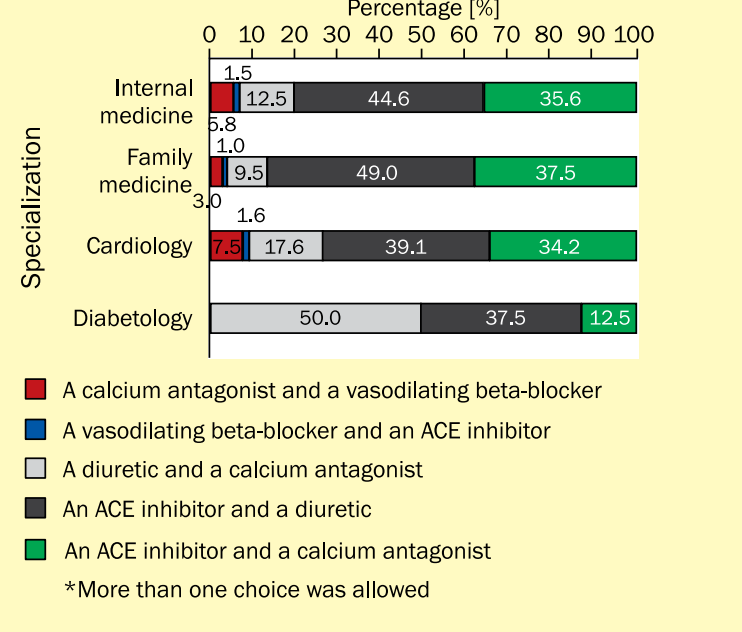

Figure 8. Suggested treatment options for resistant hypertension depending on specialization; $\mathrm{CR}$ - controlled-release; $\mathrm{XL}$ - extended-release

These trends were seen regardless of the physician age, place of work, practice settings, and professional experience. The only exception were medical professionals $<29$ years of age who would less frequently choose nebivolol and zofenopril (60.7\%), and more frequently bisoprolol and perindopril (32.1\%). Also diabetologists preferred only these two combinations in this clinical scenario.

In patients with resistant hypertension who required a 4-drug combination (diuretic, calcium antagonist, renin-angiotensin system inhibitor, and beta-blocker), the most commonly chosen regimen was a combination of furosemide, amlodipine, zofenopril, and nebivolol, indicated by $46.7 \%$ of women and $41.21 \%$ of men. The second most common regimen included torasemide, lercanidipine, telmisartan, and carvedilol and was indicated by $36.5 \%$ of women and $34 \%$ of men. Other possible options were indapamide/lacidipine/valsartan/metoprolol CR/XL, hydrochlorothiazide/verapamil/ramipril/bisoprolol, and chlorthalidon/diltiazem/perindopril/metoprolol. Only among physicians $<29$ years of age, the regimen that included furosemide was not the most frequently chosen option, second to the regimen that included torasemide $(40.7 \%$ vs. $51.9 \%)$. Diabetologists, in contrast to all other specialists, preferred the regimen that included indapamide (50\%). Suggested treatment options depending on specialization are shown in Figure 8.

\section{Discussion}

The new PTNT guidelines released in 2015 introduced a number of changes compared to both the previous 
2011 edition and the European guidelines [7]. The current edition highlights treatment individualization in relation to patient characteristics including the presence of cardiovascular risk factors, concomitant disease, and target organ damage. Modifications introduced by PTNT experts also abolish the concept of class effect by indicating specific preparations preferred in various clinical scenarios, as shown in explanations to tables summarizing the guidance regarding the choice of drug classes. The role of fixed-dose preparations in the management of hypertension has also been highlighted.

In the surveyed physician population, these guidelines were the most important source of guidance for the decisions regarding antihypertensive treatment, second to the European guidelines only among medical professionals $<29$ years of age, cardiologists, and hospital specialists. Our study findings highlight a major role of the document prepared by the PTNT experts in shaping the therapeutic attitudes of Polish physicians.

According to the 2015 PTNT guidelines, the major goal of therapy in hypertensive patients is to reduce mortality and the global risk of cardiovascular and renal complications, which may be achieved by reducing blood pressure to target values or as close these values as possible [7].

This goal was considered the most important by nearly three fourths of the participating physicians, regardless of their age, place of work, professional experience, specialization, and practice settings. Indeed, effective blood pressure reduction lowers not only cardiovascular risk (particularly that of acute coronary syndromes and stroke), but also delays progression of chronic kidney disease in patients with hypertension [8, 9]. A significant effect of the mentioned clinical conditions on patients' quality of life was a likely reason why nearly one fifth of the participants considered protection from myocardial infarction, stroke, and death the most important goal of antihypertensive treatment.

In the part of the questionnaire that focused on therapeutic choices, the participating physicians were offered specific treatment regimens or drug combinations and were asked to choose the most optimal ones in their opinion. In patients with hypertension and diabetes, the respondents most frequently chose a combination of an ACE inhibitor and a calcium antagonist, which is considered the most appropriate in the guidelines due to established outcome benefits in the high cardiovascular risk population [10]. Of note, this combination was particularly often chosen by diabetologists. The second most popular was a combination of an ACE inhibitor and a vasodilating beta-blocker, chosen by one fourth of the respondents. Currently, we have no evidence of the effectiveness of beta-blockers in preventing complications of hypertension in diabetic patients, and thus PTNT recommends beta-blockers in diabetic patients only as third or fourth choice drugs. A beneficial effect of vasodilating beta-blockers (carvedilol and nebivolol) on metabolic parameters and endothelial function was the reason of their preference within the beta-blocker class by the PTNT experts, particularly in hypertension with concomitant cardiovascular disease or diabetes [7].

A combination of an ACE inhibitor and a diuretic was considered best in a diabetic patient only by one tenth of the participating physicians, while the PTNT guidelines consider this combination equal to that of an ACE inhibitor and a calcium antagonist, although with a preference of a thiazide-like diuretic, indapamide, among diuretics [11]. The low popularity of ARB combinations among the study participants was likely due to perceived lower clinical benefits of this drug class in diabetic patients compared to ACE inhibitors. Indeed, a metaanalysis that compared both drug classes in diabetic patients confirmed a cardioprotective effect of ACE inhibitors which was not seen with ARB [12].

In patients with hypertension complicated with coronary artery disease, clinical decisions of the participating physicians mostly reflected the PTNT guidelines, although choices of specific therapeutic options showed variation in relation to age of the respondents, their place of work, and specialization. A large majority of the participating physicians chose a combination of an ACE inhibitor and a beta-blocker or a vasodilating beta-blocker. Of note, based on the results of large clinical trials, three ACE inhibitors, perindopril, ramipril, and zofenopril, are preferred in the PTNT guidelines in patients with coronary artery disease, while vasodilating preparations are recommended among beta-blockers, similarly to diabetic patients [7]. Carvedilol and nebivolol were particularly popular among diabetologists, while other physicians more frequently chose beta-blockers in general, and thus believed in a class effect.

The remaining study participants preferred adding a calcium antagonist to an ACE inhibitor or a beta-blocker, which is also appropriate according to the guidelines [7]. A small proportion of the respondents (about 4\%) would choose treatment with an ACE inhibitor and a diuretic, which is not supported in the guidelines due to availability of other regimens with a more beneficial effect on outcomes [7].

In patients with hypertension and concomitant heart failure, more than half of the respondents would choose an ACE inhibitor and a vasodilating beta-blocker, and one fourth would choose a regimen that included an ACE inhibitor and an aldosterone antagonist. Based on clinical trial data, it should be concluded that a combination of an ACE inhibitor and a beta-blocker in a patient with heart failure is more beneficial due to a documented effect of specific beta-blockers on long-term outcomes [13]. The recommended ACE inhibitors are lisinopril, ramipril, zofenopril, and trandolapril, while the recommended beta-blockers included metoprolol $\mathrm{XR} / \mathrm{CR}$, bisoprolol, carvedilol, and nebivolol. According to the guidelines, an aldosterone antagonist should be added as a further step, and eplerenone is preferred. 
A combination of an ARB and a diuretic would be chosen by less than $10 \%$ of the participating physicians. Angiotensin receptor blockers may be used in patients with heart failure who are intolerant to ACE inhibitors, and the preferred drugs are candesartan and valsartan. Also one in ten physicians would use a dihydropyridine calcium antagonist in a patient with heart failure, which is unsupported by the available scientific evidence.

In patients with hypertension and COPD, the most commonly chosen combination included an ACE inhibitor and a calcium antagonist (about 40\% of the respondents), followed by a combination of an ARB and a calcium antagonist (about $30 \%$ of the respondents). Indeed, dihydropyridine calcium antagonists are the preferred first choice drugs in this patient group due to favourable safety profile. Among the renin-angiotensin system inhibitors, ARB are recommended as unlike ACE inhibitors, these drugs do not induce cough which might provoke bronchospasm in COPD patients.

One in ten physicians, including one in four diabetologists, chose a combination of a calcium antagonist and a vasodilating beta-blocker. Such a combination is warranted if other indications for a beta-blocker exist, and drugs with cardioselective or additional protective properties should be used to minimize the effect on bronchial tree function. It is somewhat puzzling that one in five study participants would choose a diuretic for the treatment of hypertension in a patient with COPD, which is not a preferred therapy in this patient group.

According to the guidelines, in the elderly patients with isolated systolic hypertension, the treatment should be initiated with a thiazide/thiazide-like diuretic and a dihydropyridine calcium antagonist, if there are no indications to individualize therapy otherwise. This option was chosen by slightly more than $30 \%$ of the study participants, while about $40 \%$ of women and about $50 \%$ of men chose treatment with an ACE inhibitor combined with a diuretic or a calcium antagonist. According to the guidelines, renin-angiotensin system inhibitors are recommended as second line drugs when the treatment needs to be intensified. One in five study participants preferred a vasodilating beta-blocker combined with a calcium antagonist or an ACE inhibitor. In the elderly patients with isolated systolic hypertension, this combination may increase the risk of falls due to frequent occurrence of orthostatic hypotension. However, the decision to use a beta-blocker is justified in case of such concomitant conditions as coronary artery disease, heart failure, or tachyarrhythmia.

Combination antihypertensive therapy in women of reproductive age was controversial for the study participants. The most popular combination, chosen by more than one third of the participating physicians, included a vasodilating beta-blocker and a calcium antagonist. One in ten physicians would choose any beta-blocker combined with a calcium antagonist, and another $10 \%$ would recommend treatment with a diuretic and a calcium antagonist. Both combinations are considered appropriate in the guidelines, but thiazide-like diuretics (chlorthalidone, indapamide) are preferred among diuretics.

Of interest, one in four women and one in three men preferred combining a calcium antagonist with a centrally acting drug. The latter drugs lower blood pressure by inhibiting vasomotor and cardiac regulatory centres in the brainstem [14]. On the Polish market, four centrally acting antihypertensive agents are available: methyldopa ( $\alpha_{2}$-adrenergic receptor agonist), clonidine $\left(\alpha_{2}\right.$-adrenergic and imidazole receptor agonist), and rilmenidine and moxonidine (imidazole receptor agonists). Among them, only methyldopa is a first choice agent in pregnant women, and other drugs are recommended as further treatment steps ( $4^{\text {th }}$ or $5^{\text {th }}$ choice) due to no evidence of cardiovascular and mortality risk reduction in hypertensive patients.

About $10 \%$ of the respondents chose a combination of a diuretic and a vasodilating beta-blocker. This combination is considered acceptable in the guidelines but inferior to other combinations due to a risk of adverse effects on lipid and glucose metabolism and the risk of orthostatic hypotension.

In a young man with hypertension and hyperkinetic circulation inadequately controlled with monotherapy, three fourths of the respondents declared a choice of a nebivolol and zofenopril regimen. Other combinations of a beta-blocker and an ACE inhibitor, including bisoprolol/perindopril and carvedilol/quinapril, were much less popular. A marginal proportion of the respondents would choose metoprolol and quinapril or metoprolol XL/CR and trandolapril. Indeed, clinical study results indicate that nebivolol, which also releases nitric oxide, is associated with a lower risk of erectile dysfunction compared to other beta-blockers [15]. In turn, zofenopril seems to have the most beneficial pharmakokinetic profile among ACE inhibitors [16]. Due to its high lipophilicity, this drug inhibits cardiac ACE fraction effectively and longer than other drug of this class, which translates into potent action, prolonged antihypertensive effect, and postulated additional cardioprotective benefits. It is also believed that the sulfhydryl group present in the zofenopril drug structure is responsible for its antioxidant properties and a beneficial effect on lipid profile [16]. The drug also seems well tolerated [17]. In a randomized crossover study in healthy volunteers, zofenopril provoked cough following stimulation with capsaicin or citric acid significantly less frequently than ramipril [17].

Resistant hypertension, defined as blood pressure values $\geq 140 / 90 \mathrm{mmHg}$ despite use of 3 antihypertensive drugs (including a diuretic), remains a common clinical problem in Poland. According to the 2015 PTNT guidelines, following exclusion of pseudoresistance and modifiable 
causes of treatment resistance, an aldosterone antagonist should be added as a first step in patients who received the recommended three-drug combination (a renin-angiotensin system inhibitor, a diuretic, and a calcium inhibitor). Addition of a beta-blocker, preferentially with vasodilating properties, may also be considered.

In a situation requiring use of 4 antihypertensive drugs, nearly half of the respondents chose the furosemide/ /amlodipine/zofenopril/nebivolol combination among the potential combinations listed, and nearly one third chose the torasemide/lercanidipine/telmisartan/carvedilol combination. Of note, the combination including metoprolol succinate (indapamide/lacidipine/valsartan/metoprolol $\mathrm{CR} / \mathrm{XL}$ ) was chosen more frequently that the combination that included an older metoprolol preparation (chlorthalidon/diltiazem/perindopril/metoprolol) or the combination that included bisoprolol (hydrochlorothiazide/verapamil/ /ramipril/bisoprolol).

The responses of the surveyed physicians show a high position of loop diuretics (furosemide) among Polish medical professionals. At the same time, the newest drug in this class, torasemide, with a four-fold higher potency of the antihypertensive effect and better safety profile (metabolically neutral, lower risk of electrolyte disturbances), was less frequently chosen by the study participants [18].

Our study results show that compared to diltiazem and verapamil, dihydropyridine calcium antagonists are much more frequently used for the treatment of resistant hypertension. Extensive evidence of cardiovascular risk reduction with amlodipine is likely the reason why the combinations that included this drug were most frequently chosen by the study participants. Of note, however, third generation dihydropyridines lercanidipine and lacidipine, which are less popular among Polish physicians, are excellent alternatives in case of adverse effects (peripheral oedema) during treatment with amlodipine, as also noted in the newest PTNT guidelines [19].

A significantly higher popularity of the regimens including a vasodilating beta-blocker in the treatment of resistant hypertension shows that Polish medical professionals are convinced of clinical benefits from the use of these drugs. This opinion is in agreement with the position of PTNT which considers nebivolol and carvedilol preferred among beta-blockers.

When considering the management of patients with resistant hypertension, the role of fixed-dose combinations should not be neglected. Currently, Polish physicians may choose among six two-drug combinations and two three-drug combinations (perindopril/indapamide/amlodipine and valsartan/hydrochlorothiazuide/amlodipine), the use of which may improve treatment effectiveness. In addition, the results of a recent pharmacoeconomic analysis show that the use of fixed-dose combinations is associated not only with health benefits (a higher number of quality- -adjusted life days) but also significant financial benefits, both for the public payer and the patient [20].

\section{Study limitations}

When interpreting the reported study results, it should be remembered that the study group included only those physicians who responded to the survey. It may be suspected that medical professionals who agreed to participate were also likely to increase their knowledge actively, were familiar with the 2015 PTNT guidelines, published 2 months before the study initiation, and had their own opinion on new antihypertensive medications, based on the available clinical study results and the marketing activity of the pharmaceutical companies. The results regarding the choice of treatment regimens and specific medications within a class reflected suggestions offered in the survey, from which the physicians chose the most optimal combinations of drug classes and/or preparations in their opinion.

The correspondence nature of the survey allowed responses to be made based on other sources than personal knowledge and clinical experience. We are unable to exclude that the declared responses were changed after discussion with peers or consulting medical literature.

Finally, the structure of the study group that included three times more physicians working in outpatient settings than in hospital settings, does not allow extending the conclusions made to both physician populations. In addition, a marginal proportion of diabetologists participating in the study likely made our results less representative for this group of specialists.

\section{Conclusions}

1. Our data show a homogeneous physician attitude towards antihypertensive treatment. The management was mostly guided by the Polish PTNT guidelines or European ESH/ESC guidelines. 2. In hypertensive patients with concomitant diabetes, the most commonly indicated regimen included an ACE inhibitor and a calcium antagonist, and a combination of an ACE inhibitor and a beta-blocker or a vasodilating beta-blocker was most commonly chosen in patients with hypertension and coronary artery disease. The latter combination was also most frequently indicated in patients with hypertension complicated with heart failure. In patients with COPD, the most popular combination included an ACE inhibitor and a calcium antagonist, while a combination of a diuretic and a calcium antagonist was most commonly indicated for the elderly patients with isolated systolic hypertension. Women of reproductive age were most likely to receive a vasodilating beta-blocker and a calcium antagonist, and a combination of nebivolol and zofenopril was suggested for young men with hyperkinetic circulation. 3. The most popular regimen in patients with 
resistant hypertension included furosemide, amlodipine, zofenopril, and nebivolol, followed by torasemide, lercanidipine, telmisartan, and carvedilol. 4. Our results show clear preferences of Polish medical professionals regarding specific antihypertensive medications within drug classes. These included vasodilating beta-blockers, newer ACE inhibitors (zofenopril), dihydropyridine calcium antagonists, and loop diuretics. These preferences are generally in agreement with the PTNT guidelines, except for recommendations regarding loop diuretics, which should have much lower position in the antihypertensive treatment compared to thiazide/thiazide-like diuretics according to the PTNT experts.

\section{Sources of funding}

The study was supported by a research grant from Berlin Chemie Menarini Polska sp. z o.o., a conducted by the research company QAH sp. z o.o., based in Łódź.

\section{Acknowledgements}

The authors would like to thank the study sponsor, Berlin Chemie Menarini Polska sp. z o.o., for financial support for this project, and QAH Sp. z 0.0. for conducting the survey, preparing the report, and statistical analysis of the data.

\section{Conflict of interest(s)}

Study co-authors did not receive any honoraria for conducting the study, and the main author and the senior author of the study (KJF, AT) received honoraria from the study sponsor for designing the questionnaire, preparing the survey items, and developing the study concept. Co-authors were consultants and participated in preparation of the final study report. The study sponsor had no effect on the final study report, the process of its preparation, and publications.

\section{Streszczenie}

Wstęp. Nadciśnienie tętnicze jest najczęściej występującym modyfikowalnym czynnikiem ryzyka chorób układu sercowo-naczyniowego i przedwczesnego zgonu w skali globalnej. Dostępność nowych preparatów hipotensyjnych o unikatowych właściwościach farmakologicznych zwiększa skuteczność i bezpieczeństwo leczenia nadciśnienia tętniczego. Celem ankietowego badania ALMONDS była identyfikacja postaw polskich lekarzy wobec nowych leków stosowanych w terapii nadciśnienia tętniczego, ze szczególnym uwzględnieniem opinii na temat „efektu klasy” w obrębie leków hipotensyjnych.

Materiał i metody. Badanie przeprowadzono w formie wystandaryzowanej ankiety, którą wypełniło 784 lekarzy specjalistów lub specjalizujących się w kardiologii, chorobach wewnętrznych, medycynie rodzinnej i diabetologii. Forma listowna i anonimowość kwestionariusza ankietowego pozwoliły zmaksymalizować wiarygodność uzyskanego materiału.

Wyniki. Wśród lekarzy biorących udział w badaniu dominowały kobiety; osoby w wieku 46-60 lat. Znaczący odsetek lekarzy uzyskał specjalizację z chorób wewnętrznych i w zawodzie pracował od ponad 20 lat. W leczeniu chorych kierowano się głównie wytycznymi Polskiego Towarzystwa Nadciśnienia Tętniczego (PTNT) lub wytycznymi europejskimi - European Society of Hypertension (ESH)/European Society of Cardiology (ESC). W przypadku współwystępowania u chorych na nadciśnienie tętnicze choroby wieńcowej najczęściej sięgano po beta-adrenolityki oraz inhibitor ACE, w tym inhibitor ACE i wazodylatacyjny beta-adrenolityk. Połączenie to było również najczęściej wybierane u chorych z nadciśnieniem tętniczym powikłanym niewydolnością serca. W przypadku kobiet w wieku rozrodczym najchętniej wybierano wazodylatacyjny beta-adrenolityk i antagonistę wapnia, natomiast w przypadku młodych mężczyzn z objawami zespołu hiperkinetycznego deklarowano wybór nebiwololu i zofenoprilu. U chorych z opornym nadciśnieniem tętniczym najczęściej stosowano: furosemid/amlodipinę/zofenopril/nebiwolol. Innym często wskazywanym schematem terapeutycznym był: torasemid/lerkanidipina/telmisartan/karwedilol.

Wnioski. Wyniki badania wskazują na istnienie wśród polskich specjalistów wyraźnych preferencji dotyczących konkretnych preparatów hipotensyjnych należących do poszczególnych klas. Wśród beta-adrenolityków preferowane są leki o właściwościach wazodylatacyjnych, wśród inhibitorów ACE - nowsze leki, wśród antagonistów wapnia - preparaty dihydropirydynowe, a wśród leków moczopędnych - diuretyki pętlowe. Stanowisko to pozostaje w dużej mierze spójne z zaleceniami PTNT z 2015 roku.

Słowa kluczowe: nadciśnienie tętnicze, leki hipotensyjne, wytyczne, ankiety w opiece zdrowotnej

Folia Cardiologica 2016; 11, 2: 85-95 


\section{References}

1. Lawes C.M., Vander Hoorn S., Rodgers A. et al. Global burden of blood-pressure-related disease, 2001. Lancet 2008; 371: 1513-1218 .

2. Dostępne na: http://www.world-heart-federation.org/cardiovascular-health/cardiovascular-disease-risk-factors/hypertension/. Data dostępu: 11.01.2016.

3. Zdrojewski T., Rutkowski M., Bandosz P. et al. Prevalence and control of cardiovascular risk factors in Poland. Assumptions and objectives of the NATPOL 2011 Survey. Kardiol. Pol. 2013; 71: 381-392.

4. Kuulasmaa K., Tunstall-Pedoe H., Dobson A. et al. Estimation of contribution of changes in classic risk factors to trends in coronary-event rates across the WHO MONICA Project populations. Lancet 2000; 355: 675-687.

5. Ruzicka M., Hiremath S. Can drugs work in patients who do not take them? The problem of non-adherence in resistant hypertension. Curr. Hypertens. Rep. 2015; 17: 579.

6. Steinman M.A., Fischer M.A., Shlipak M.G. Clinician awareness of adherence to hypertension guidelines. Am. J. Med. 2004; 117: 747-754.

7. Tykarski A., Narkiewicz K., Gaciong Z. Zasady postępowania w nadciśnieniu tętniczym - 2015 rok. Nadciś. Tętn. Prakt. 2015; 1: 1-70.

8. Lewington S., Clarke R., Qizilbash N. et al. Age-specific relevance of usual blood pressure to vascular mortality: a meta-analysis of individual datafor one million adults in 61 prospective studies. Lancet 2002; 360: 1903-1913.

9. Palit S., Chonchol M., Cheung A.K. Association of BP with death, cardiovascular events, and progression to chronic dialysis in patients with advanced kidney disease. Clin. J. Am. Soc. Nephrol. 2015; 10: 934-940.

10. Jamerson K., Weber M.A., Bakris G.L. et al. Benazepril plus amlodipine or hydrochlorothiazide for hypertension in high-risk patients. N. Engl. J. Med. 2008; 359: 2417-2428.

11. Patel A., MacMahon S., Chalmers J. et al. Effects of a fixed combination of perindopril and indapamide on macrovascular and microvascu- lar outcomes in patients with type 2 diabetes mellitus (the ADVANCE trial): a randomised controlled trial. Lancet 2007; 370: 829-840.

12. Cheng J., Zhang W., Zhang X. et al. Effect of angiotensin-converting enzyme inhibitors and angiotensin II receptor blockers on all-cause mortality, cardiovascular deaths, and cardiovascular events in patients with diabetes mellitus: a meta-analysis. JAMA Intern. Med. 2014; 174: 773-185.

13. Mancia G., Fagard R., Narkiewicz K. et al. 2013 ESH/ESC Guidelines for the management of arterial hypertension: the Task Force for the management of arterial hypertension of the European Society of Hypertension (ESH) and of the European Society of Cardiology (ESC). J. Hypertens. 2013; 31: 1281-1357.

14. Widecka K. Leki alfa-adrenolityczne i działające centralnie. Nadciś. Tętn. 2007; (supl. A): A1-A26.

15. Fongemie J., Felix-Getzik E. A review of nebivolol pharmacology and clinical evidence. Drugs 2015; 75: 1349-1371.

16. Evangelista S., Manzini S. Antioxidant and cardioprotective properties of the sulphydryl angiotensin-converting enzyme inhibitor zofenopril. J. Int. Med. Res. 2005; 33: 42-54.

17. Lavorini F., Chellini E., Innocenti M. A crossover randomized comparative study of zofenopril and ramipril on cough reflex and airway inflammation in healthy volunteers. Cough 2014; 10: 7.

18. Dunn C.J., Fitton A., Brogden R.N. Torasemide. An update of its pharmacological properties and therapeutic efficacy. Drugs 1995; 49: 121-142.

19. Makarounas-Kirchmann K., Glover-Koudounas S., Ferrari P. Results of a meta-analysis comparing the tolerability of lercanidipine and other dihydropyridine calcium channel blockers. Clin. Ther. 2009; 31: 1652-1663.

20. Kawalec P., Holko P., Stawowczyk E. et al. Analiza ekonomiczna dotycząca preparatu złożonego zawierającego indapamid i amlodipinę w terapii nadciśnienia tętniczego w warunkach polskich. Kardiol. Pol. 2015; 73: 768-780. 